\title{
THE CONCEPT OF TRAINING IT PROFESSIONALS IN THE CROSS-CUTTING DIGITAL TECHNOLOGIES
}

\author{
E.N. Cheremisina, N.A. Tokareva ${ }^{\text {a }}$ E.Yu. Kirpicheva, O.A. Kreider, \\ A.A. Milovidova, S.V. Potemkina
}

Dubna State University, Universitetskaya 19, 141980, Dubna, Russia

E-mail: ${ }^{a}$ tokareva@uni-dubna.ru

\begin{abstract}
The emergence of the new generation digital technologies, which were called "cross-cutting" due to the scale and depth of impact, determined a large-scale transformation of business and social sphere models. These changes have a strong impact on the content of professional activities: employees are required to have new skills and, consequently, new competencies. The rapid digitalization of the economy requires qualified experts. Currently there is a severe shortage of IT experts required for the development of national projects in Russia. Formation of educational programs that meet global trends, taking into account the most popular technologies, has the particular importance. These technologies and their subtechnologies are described in roadmaps created within the framework of the national program "Digital Economy of the Russian Federation". The report presents a system of training highly qualified IT experts in cross-cutting digital technologies at the Institute for Systems Analysis and Management (ISAM) of the Dubna State University.
\end{abstract}

Keywords: Cross-cutting digital technologies, IT education, system approach

Evgenia Cheremisina, Nadezhda Tokareva, Elena Kirpicheva, Oksana Kreider, Anna Milovidova, Snezhana Potemkina 


\section{Introduction}

Currently there is a severe shortage of IT experts required for the development of national projects in Russia. The rapid digitalization of the economy requires qualified experts.

The Government of the Russian Federation has formed a national program "Digital Economy of the Russian Federation", one of the goals of which is to solve the issue of ensuring the accelerated introduction of digital technologies in the economy and social sphere [1]. A number of federal projects are being developed within the framework of this program: "Normative Regulation of the Digital Environment", "Human Resources for the Digital Economy", "Information Infrastructure", "Information Security", "Digital Technologies", "Digital Public Administration", "Artificial Intelligence".

The main goal of the federal project "Human Resources for the Digital Economy" is to provide training of highly qualified personnel for the digital economy. It is achieved through performing several tasks, in particular: meeting the labor market needs for experts in the field of IT and information security, as well as for experts with digital competencies who have been trained in the relevant programs of higher and secondary vocational education.

The emergence of the new generation digital technologies, which were called "cross-cutting" due to the scale and depth of impact, determined a large-scale transformation of business and social sphere models. These changes have a strong impact on the content of professional activities: employees are required to have new skills and, consequently, new competencies.

Formation of educational programs that meet global trends, taking into account the most popular technologies, has the particular importance. These technologies and their subtechnologies are described in roadmaps created within the framework of the national program "Digital Economy of the Russian Federation": neurotechnologies and artificial intelligence, virtual and augmented reality technologies, distributed ledger technologies, quantum technologies, new production technologies, robotics and sensorics components, wireless communication technologies.

Thus, in connection with the transition to the digital economy, professional education faced challenging tasks. In response to these challenges, the Institute for Systems Analysis and Management of Dubna State University adopted and develops a teaching concept that allows to combine traditional methods and approaches in the educational process with innovative digital solutions and tools [2-11].

\section{Development of the teaching concept at the Institute for Systems Analysis and Management of Dubna State University}

The main directions of development in the IT experts training at Dubna State University are:

- Cooperation with employing companies which will provide a practical component in the learning process and significantly increase the competitiveness and demand for graduates. The following main forms of cooperation can be distinguished into: conducting master classes, lectures, job fairs, etc.; participation of companies in the organization of production and predegree practices; training through the project and research work and the formation of collections of application tasks; arranging competitive events, hackathons, sponsoring intra-university projects. The ISAM partner companies include: Joint Institute for Nuclear Research, Yandex, the Federal Government Agency "NALOG-SERVIS" of the Federal Tax Service of Russia, Sberbank, Federal Budgetary State Institution All-Russian Geological Research and Development Oil Institute, the Russian Federal Geological Fund, enterprises of the special economic zone Dubna SEZ and many others.

- Project activities. The validity of project activities in the educational process of the university stems from the need to ensure the competitiveness of the university and its graduates, who must have the required competence in their future profession by the end of their studies. The main advantages of the students' project activities at the university are their research and interdisciplinary nature, 
proximity to the specifics of future professional activities. This is precisely the complexity of its implementation, since a deep mastery of the material of various, non-related disciplines is required for effective work on a project. ISAM students master and actively apply in training such modern methodologies for organizing project activities as Scrum and Kanban. The technology stack used in the project activities of students includes: Moodle, Trello, GitHub, Jira, Slack, etc.

- Research and development work. The effectiveness of training future specialists depends on the degree of involvement in research and development work, the provision of a research base, knowledge of the methodology of scientific work. Attracting students to research work allows them to use their creative and intellectual potential to solve urgent problems of modern science. It should be noted that the work organization forms are divided into those included in the educational process and complementary to it. Within the framework of the complementary work organization forms, the participation of students individually or in a team in state budgetary and contractual scientific research together with university professors is envisaged.

\section{A stack of cross-cutting digital technologies that students study at the Institute for Systems Analysis and Management}

New requirements for the basic competencies of a modern IT specialist in digital transformation in the context of sustainable development and the transition to a digital economy were formulated by us in [2] and include:

- the ability for close communication and cooperation in a digital environment using online tools for digital collaboration;

- the ability for self-organization and self-development in conditions of uncertainty;

- developed creative thinking, which determines the ability to rebuild the existing ways of solving problems, to put forward alternative options for action;

- the ability to manage information and big data;

- the ability to create innovative products and services in order to improve the management efficiency and competitiveness of organizations.

The learning paths in the educational system of ISAM are organized in a manner that allows to provide an up-to-date foundation of basic knowledge and consistent development of cross-cutting (interdisciplinary) knowledge and technologies, without which it is practically impossible to create and use information technologies for providing information and analytical activities, decision support, and creating innovative products and services. The training program subjects ensuring the formation of general and professional competencies are represented by the following blocks:

- Analytical and project activities.

- Programming (basic and advanced levels).

- Cross-cutting knowledge and technologies (common to all fields and corresponding to educational program specializations).

As an example, let us discuss the learning path of undergraduate students in the field of "Informatics and Computer Engineering" studying in the "System Engineering" specialization. The areas of professional activity of graduates include development, research and application of modern software; methods and models of objects, systems, processes and technologies intended for analysis and preparation of solutions in all spheres of social, economic, industrial, management activities.

During the first two years of study, students master the disciplines mainly of the basic and general professional parts of the educational program, which form the theoretical and methodological basis of the IT field.

The technological stack in the study of junior disciplines includes:

- For the analytical and project activities disciplines (informatics, information systems and technologies, optimization methods, decision theory, the basics of project activities): MS Office, 
GoogleDocs, Collab, Bitrix, LMS, Work-flow, GIS, analytical low-code platforms (Loginom), Jira, Trello, GitHub.

- For the basic level programming disciplines (introduction to programming, object-oriented programming, computer practice, architecture of computing systems, structures and algorithms for data processing, WEB-technologies, development of WEB-applications, database technologies): Microsoft .NET Framework, C\#, Python, C++, openMP, MPI, HTML5, CSS3, JavaScript, PHP, JavaScript, Nod.js, SQL - APEX Oracle, Oracle 12c;

- For the disciplines related to the basics of cross-cutting technologies (engineering graphics, networks and telecommunications, etc.): Autodesk Inventor, Compass 3D, Wireshark Network analyzer, Citrix XenApp Platinum Edition.

The senior courses provide an opportunity for a deeper mastery of cross-cutting digital technologies and obtaining interdisciplinary knowledge with the possibility of choosing specialized disciplines and obtaining in-depth knowledge in the most interesting areas.

The technology stack includes:

- System analysis and design: Matlab, Microsoft .NET Framework, Anylogic, SADT, UML: Visual Paradigm, Flexberry PLATFORM, StarUML, etc.

- DBMS: Oracle, MongoDB, Neo4.

- Programming (advanced level): C/C++, Linux and Windows OS families, Java (Hibernate, Spring, Android Studio, Java/Kotlin SQLite).

- Software quality assessment: Selenium IDE, Jmeter, Axure, Proto.io.

- Robotics and sensing components. Human-machine interaction: Figma, Microsoft HTML Help Workshop, Help\&Manual, RoboHELP, AuthorIT, DocBook/XML, DITA, Cybersafe Top Secret, Arduino IDE;

- Neurotechnology and Artificial Intelligence: Python, R, Spark, Sklearn, Tensorflow, Keras, PyMorph, etc. for NLP, SciPy, NumPy, Matplotlib, FuzzyLogic and Multi-agent system (Matlab, Anylogic, NetLogo).

- New production technologies: Matlab, Anylogic, NetLogo, etc.; SADT, UML (Visual Paradigm, Flexberry PLATFORM, StarUML), Scada systems, GIS systems.

- Virtual and augmented reality technologies: C\#, C++, Kotlin, Unity, Blender, Recap360, WebGL frameworks (Three.js and Babylon.js).

- Distributed ledger technologies: Erachain blockchain, Ethereum.

An extensive laboratory base is provided in order to ensure a continuous educational process for the training of specialists with theoretical and practical competencies in the field of cross-cutting digital technologies. Let's list some of them:

-3D Modeling and Printing Laboratory (cross-cutting digital technologies: new production technologies; systems of virtual and augmented reality).

- Cloud Computing and Supercomputer Support Center. Virtual Computer Laboratory (crosscutting digital technologies: big data, distributed ledger systems).

- Artificial Intelligence Center. Virtual and Augmented Reality Laboratory (cross-cutting digital technologies: virtual and augmented reality systems, neurotechnology and artificial intelligence).

Computer Laboratory of Advanced Computing Systems (cross-cutting digital technologies: neurotechnology and artificial intelligence, quantum technologies, new production technologies).

- Network Laboratory (cross-cutting digital technologies: wireless technology).

\section{Conclusion}

The training in cross-cutting technologies at the Institute for Systems Analysis and Management of Dubna State University is carried out on the basis of a systematic approach. The elements included in the education system interact through interdisciplinary relationships, collaboration with employing companies and a practice-oriented learning paradigm. Graduates of the Institute are trained for professional activities in the field of solving the problems of digital transformation in various sectors of the economy. 


\section{References}

[1] Passport of the national project "National Program "Digital Economy of the Russian Federation" (approved by the Presidium of the Council under the President of the Russian Federation for Strategic Development and National Projects, minutes of 06/04/2019 N 7) // Access from the reference legal system "ConsultantPlus" http://www.consultant.ru/.

[2] Belov M.A., Grishko S.I., Lishilin M.V., Osipov P.A., Cheremisina E.N Strategy for Training IT Professionals Using the Innovative Training Data Center "Virtual Computer Lab" to Effectively Solve the Problems of Digital Transformation and Acceleration of the Digital Economy // Modern Information Technologies and IT-Education. Vol. 17, No 1, 2021.

[3] Belov M.A., Korenkov V.V., Potemkina S.V., Lishilin M.V., Cheremisina E.N., Tokareva N.A., Krukov Y.A. Methodical aspects of training data scientists using the data grid in a virtual computer lab environment // CEUR Workshop Proceedings. V. 2507. NEC' 2019 - Proceedings of the XXVII International Symposium on Nuclear Electronics \& Computing (NEC'2019), Budva, Becici, Pp. 236240.

[4] Cheremisina E.N., Tokareva N.A., Kreider O.A., Tyatyushkina O.Yu., Streltsova O.I. Concept for the development of the digital platform for education at dubna state university// CEUR Workshop Proceedings. V. 2507. NEC' 2019 - Proceedings of the XXVII International Symposium on Nuclear Electronics \& Computing (NEC'2019), Budva, Becici, Pp. 251-255.

[5] Belov M.A., Lupanov P.Ye., Minzov A.S., Tokareva N.A. Sistema upravleniya virtual'noy infrastrukturoy na osnove vizual'nykh modeley v srede virtual'noy komp'yuternoy laboratorii [Virtual infrastructure management system based on visual models in a virtual computer laboratory environment] // Sovremennaya nauka: aktual'nyye problemy teorii i praktiki. Seriya: Yestestvennyye i tekhnicheskiye nauki. 2019. № 6-2. S. 41-46.

[6] Adam G., Bashashin M., Podgainy D., Streltsova O., et al. IT-ecosystem of the HYBRILIT heterogeneous platform for high-performance computing and training of IT-specialists // CEUR Workshop Proceedings. V. 2267. GRID 2018 - Selected Papers of the 8th International Conference «Distributed Computing and Grid-Technologies in Science and Education». 2018. Pp. 638-644.

[7] Belov M.A., Krukov Y.A., Mikheev M.A., Lupanov P.E., Tokareva N.A., Cheremisina E.N. Essential aspects of IT training technology for processing, storage and intellectual analysis of the big data using the virtual computer lab // CEUR Workshop Proceedings. V. 2267. GRID 2018 - Selected Papers of the 8th International Conference «Distributed Computing and Grid-Technologies in Science and Education». 2018. Pp. 207-212.

[8] Cheremisina E.N., Finkel'shteyn M.YA., Lyubimova A.V. GIS INTEGRO importozameshchayushchiy programmno-tekhnologicheskiy kompleks dlya resheniya geologogeofizicheskikh zadach [GIS INTEGRO - the import-substituting software and technology complex for solving geological and geophysical problems] // Geoinformatika. 2018. № 3. S. 8-17.

[9] Cheremisina E.N., Belaga V.V., Kreyder O.A., Kirpicheva Ye.YU. Adaptivnaya strategiya podgotovki kadrov dlya zadach tsifrovoy ekonomiki v gosudarstvennom universitete «Dubna» [Adaptive training strategy for the tasks of the digital economy at Dubna State University] // Sovremennyye informatsionnyye tekhnologii i IT-obrazovaniye. 2017. T. 13. № 2. S. 140-145.

[10] Reshetnikov A.G., Tyatyushkina O.YU., Ul'yanov S.V. Intellektual'naya robototekhnika CH.3: Kontseptsiya kognitivnogo obucheniya - intellektual'nyy robotrenazher [The concept of cognitive learning - an intelligent robot simulator // System analysis in science and education] // Sistemnyy analiz v nauke i obrazovanii. 2017. № 1. S. 48-58.

[11] Koren'kov V.V., Podgaynyy D.V., Strel'tsova O.I. Obrazovatel'naya programma po tekhnologiyam HPC na baze geterogennogo klastera HYBRILIT (LIT OIYAI) [HPC technology education program based on the heterogeneous cluster HYBRILIT (LIT JINR)] // Sovremennyye informatsionnyye tekhnologii i IT-obrazovaniye. 2017. T. 13. № 4. S. 141-146. 